\title{
ANALISIS PERAMALAN PRODUKSI, KONSUMSI DAN HARGA JAGUNG DI PROVINSI NUSA TENGGARA BARAT
}

\section{FORECASTING ANALYSIS OF CORN PRODUCTION, CONSUMPTION AND PRICE IN WEST NUSA TENGGARA PROVINCE}

\author{
Moh. Iqbal Al-Qarazi, Sukardi, dan Anwar
}

Program Studi Agribisnis Fakultas Pertanian Universitas Mataram

\begin{abstract}
ABSTRAK
Penelitian ini dilaksanakan dengan tujuan: (1) Memproyeksi jumlah produksi Jagung di Nusa Tenggara Barat tahun 2020-2025, (2) Memproyeksi jumlah konsumsi Jagung di Nusa Tenggara Barat tahun 2020-2025, (3) Memproyeksi harga Jagung di Nusa Tenggara Barat tahun 2020-2025. Penelitian ini menggunakan metode data runtut waktu (time series) dengan unit analisis yang digunakan adalah produksi jagung, konsumsi jagung, dan harga jagung di Provinsi NTB. Jenis data yang digunakan adalah jenis data sekunder dengan studi kepustakaan sebagai teknik pengumpulan data. Penelitian ini menggunakan beberapa analisis data diantaranya adalah metode double moving average, double exponential smothing, tren linier, tren kuadratik dan ARIMA. Hasil penelitian menunjukkan bahwa (1) jumlah produksi jagung di Provinsi Nusa Tenggara Barat pada tahun 2020 - 2025 secara berturut-turut sebanyak 2.902.254,90 ton, 3.264.611,35 ton, 3.626.967,81 ton, 3.989.324,27 ton, 4.351.680,73 ton dan 4.714.037,19 ton. (2) jumlah konsumsi jagung di Provinsi Nusa Tenggara barat pada tahun 2020 - 2025 secara berturut-turut sebanyak 7.447,89 ton, 7.744,33 ton, 8.040,78 ton, 8.337,22 ton, 8.633,67 ton dan 8.930,11 ton. (3) harga jagung di Provinsi Nusa Tenggara Barat pada tahun 2020 - 2025 rata-rata secara berturut-turut sebesar Rp. 5.451, Rp. 5.581, Rp. 5.712, Rp. 5.843, Rp. 5.974 dan Rp. 6.105.
\end{abstract}

Kata kunci: Produksi, Konsumsi, Harga, Peramalan.

\section{ABSTRACT}

This research was carried out with the aim of: (1) Projecting the amount of maize production in West Nusa Tenggara in 2020-2025, (2) Projecting the amount of maize consumption in West Nusa Tenggara in 2020-2025, (3) Projecting the price of Maize in West Nusa Tenggara in 2020-2025. This study used data method runtut time (time series) with the analysis unit used is corn production, corn consumption, and corn prices in NTB Province. The type of data used is a secondary type of data with literature studies as a data collection technique. This research uses several data analysis including double moving average method, double exponential smothing, linear trend, quadratic trend and ARIMA. The results showed that (1) the total maize production in West Nusa Tenggara Province in 2020-2025 was 2,902,254.90 tons, respectively. 3,264,611.35 tons, 3,626,967.81 tons, 3,989,324.27 tons, 4,351,680.73 tons and 4,714,037.19 tons. (2) the total maize consumption in west Nusa Tenggara Province in 
2020-2025 is 7,447.89 tons, respectively, 7,744.33 tons, 8,040.78 tons, 8,337.22 tons, 8,633.67 tons and 8,930.11 tons. (3) The price of maize in West Nusa Tenggara Province in 2020-2025 is Rp. 5,451, Rp. 5,581, Rp. 5,712, Rp. 5,843, Rp. 5,974 and Rp. 6,105.

Keywords: Production, Consumption, Price, Forecasting

\section{PENDAHULUAN}

Pertanian menempati kedudukan strategis dalam pembangunan nasional Indonesia. Sejumlah besar penduduk mempunyai mata pencaharian di sektor pertanian, termasuk sektor tanaman pangan, perkebunan, peternakan, kehutanan, dan perikanan, baik secara langsung maupun tidak langsung.

Diantara berbagai subsektor yang ada dalam bidang pertanian mulai dari subsektor tanaman pangan, subsektor tanaman hortikultura, subsektor perkebunan dan subsektor peternakan. Subsektor tanaman pangan masih dominan menjadi fokus masalah negeri ini untuk diselesaikan dalam memenuhi kebutuhan dalam negeri. Untuk itulah dalam Renstra Kementerian Pertanian (2020-2024) yang mengatakan bahwa komoditas strategis pertanian merupakan komoditas-komoditas pertanian yang bernilai ekonomi cukup tinggi untuk menjaga ketahanan pangan (stabilitas harga) agar tidak terjadi inflasi. Komoditas-komoditas strategis tersebut diantaranya komoditas padi, jagung, kedelai, cabai, bawang, tebu dan daging sapi/kerbau.

Nusa Tenggara Barat merupakan salah satu provinsi yang menjadi sentra produksi jagung, sebab memiliki sumber saya yang potensial untuk menunjang produksi jagung. Komoditas jagung mendapatkan perhatian lebih dari pemerintah dalam kebijakan pangan, hal tersebut dikuatkan dengan adanya program "PIJAR" (sapi, jagung dan rumput laut). Selain "PIJAR" terdapat juga program "UPSUS PAJALE" (Upaya Khusus Padi, Jagung dan Kedelai). Program-program tersebut memperlihatkan hasil yang signifikan, hal tersebut dapat dilihat dari peningkatan luas panen, produksi dan produktivitas jagung pada tahun 2001 sampai 2019 pada Tabel 1.

Permintaan jagung akan terus meningkat dari tahun ke tahun baik itu untuk kebutuhan pangan, industri bahan makanan, bahan baku pakan, berbagai produk industri turunan berbasis jagung, bahkan untuk keperluan bahan baku energi (bioetanol). Sementara sisi konsumsi terus meningkat, sisi produksi jagung nasional masih rendah, maka akan menyebabkan ketimpangan dalam memenuhi kebutuhan akan jagung. Oleh karena itu juga perlu untuk diketahui jumlah produksi, konsumsi dan harga jagung pada beberapa tahun ke depan. Fluktuasi produksi, harga dan konsumsi menyebabkan pemangku kebijakan akan mengalami kesulitan dalam merumusakan dan membuat kebijakan serta kesulitan dalam mengawasi perubahan ketiga varibel tersebut. Salah satu cara untuk mengetahui kemampuan Provinsi Nusa Tenggara Barat dalam memproduksi jagung serta tingkat konsumsi dan tingkat harga adalah dengan melakukan peramalan sehingga akan mempermudah pemangku kebijakan dalam menyusun perencanaan serta pengambilan keputusan di masa mendatang. Hal inilah yang menjadikan peramalan memiliki peran yang strategis sebagai tolak ukur sebuah kebijakan. Untuk itulah dilakukan penelitian yang berjudul "Analisis Peramalan Produksi, Konsumsi dan Harga Jagung di Provinsi Nusa Tenggara Barat". 
Tabel 1. Perkembangan Luas Panen, Produksi, dan Produktivitas Jagung di Nusa Tenggara Barat Tahun 2013-2019

\begin{tabular}{ccccccccc}
\hline & \multicolumn{3}{c}{ Indikator } & & \multicolumn{3}{c}{ Indikator } \\
\cline { 2 - 3 } Tahun & $\begin{array}{c}\text { Luas } \\
\text { Panen } \\
\text { (Ha) }\end{array}$ & $\begin{array}{c}\text { Produksi } \\
\text { (Ton) }\end{array}$ & $\begin{array}{c}\text { Produktivitas } \\
\text { (Ton/Ha) }\end{array}$ & Tahun & $\begin{array}{c}\text { Luas } \\
\text { Panen } \\
\text { (Ha) }\end{array}$ & $\begin{array}{c}\text { Produksi } \\
(\text { Ton) }\end{array}$ & $\begin{array}{c}\text { Produktivitas } \\
\text { (Ton/Ha) }\end{array}$ \\
\hline 2001 & 24.969 & 50.778 & 20,34 & & & & \\
2002 & 28.847 & 57.785 & 20,03 & 2011 & 89.307 & 456.915 & 51,16 \\
2004 & 31.217 & 64.228 & 20,57 & 2012 & 117.030 & 642.674 & 54,92 \\
2004 & 33.140 & 71.275 & 21,51 & 2013 & 110.273 & 633.773 & 57,47 \\
2005 & 39.389 & 96.459 & 24,49 & 2014 & 126.577 & 785.864 & 62,09 \\
2006 & 40.617 & 103.963 & 25,60 & 2015 & 143.117 & 959.973 & 67,08 \\
2007 & 42.955 & 120.612 & 28,08 & 2016 & 206.885 & 1.278 .271 & 61,79 \\
2008 & 59.078 & 196.263 & 33,22 & 2017 & 310.990 & 2.127 .324 & 68,40 \\
2009 & 81.543 & 308.863 & 37,88 & 2018 & 326.377 & 2.084 .928 & 63,88 \\
2010 & 61.953 & 249.005 & 40,43 & 2019 & 362.092 & 2.494 .931 & 68,90 \\
\hline
\end{tabular}

Sumber: Kementerian Pertanian, Dinas Pertanian dan Perkebunan NTB (Diolah)

\section{METODOLOGI PENELITIAN}

\section{Metode Penelitian}

Penelitian ini menggunakan metode data runtut waktu (time series) dengan menggunakan data yang dikumpulkan, dicatat, atau diobservasi sepanjang waktu yang berurutan untuk menjelaskan atau memperlihatkan prilaku serial data tersebut.

\section{Unit Analisis}

Unit analisis mengacu pada keseluruhan data yang akan dianalisis dan dijelaskan (Vaus, 2005). Berdasarkan pernyataan Vaus ini, maka yang dimaksud dengan unit analisis dalam penelitian ini meliputi produksi jagung, konsumsi jagung, dan harga jagung, yang mana kesemua data ini (produksi jagung, konsumsi jagung, dan harga jagung) diperoleh dari beberapa instansi, yakni Dinas Pertanian dan Perkebunan Provinsi NTB, Dinas Ketahanan Pangan Provinsi NTB, dan Dinas Perdagangan Provinsi NTB.

\section{Variabel dan Cara Pengukuran}

1. Produksi adalah jumlah produk jagung dari hasil panen yang ada di Provinsi Nusa Tenggara Barat yang dinyatakan dalam satuan ton.

2. Konsumsi adalah jumlah jagung yang digunakan oleh masyarakat yang ada di Provinsi Nusa Tenggara Barat yang dinyatakan dalam satuan ton.

3. Harga adalah harga jual jagung yang berlaku di Provinsi Nusa Tenggara Barat yang dinyatakan dalam satuan rupiah per kilogram $(\mathrm{Rp} / \mathrm{Kg})$. 


\section{Teknik Pengumpulan Data}

Pengumpulan data dalam penelitian ini dilakukan dengan cara studi kepustakaan. Menurut Nazir (2013) studi kepustakaan adalah teknik pengumpulan data dengan mengadakan studi penelaahan terhadap buku-buku, literatur-literatur, catatancatatan dan laporan-laporan yang ada hubungannya dengan masalah yang ingin dipecahkan.

\section{Analisis Data}

\section{Metode Double Moving Average}

$$
\begin{aligned}
& \mathrm{S}_{\mathrm{t}}=\frac{(\mathrm{Xt}+\mathrm{Xt}-1+\cdots+\mathrm{Xt}-\mathrm{n}+1)}{n} \\
& \mathrm{~S}^{\prime}{ }_{\mathrm{t}}=\frac{(\mathrm{S} / \mathrm{t}+\mathrm{S} / \mathrm{t}-1+\cdots+\mathrm{St}-\mathrm{n}+1)}{n} \\
& \mathrm{a}_{\mathrm{t}}=\mathrm{S}_{\mathrm{t}}+\left(\mathrm{S}_{\mathrm{t}}{ }-\mathrm{S}^{\prime}{ }_{\mathrm{t}}\right) \\
& \mathrm{b}_{\mathrm{t}}=\frac{2}{v-1}\left(\mathrm{~S}^{\prime} t-S^{\prime \prime} \mathrm{t}\right) \\
& \mathrm{F}_{\mathrm{t}+\mathrm{m}}=\mathrm{a}_{\mathrm{t}}+\mathrm{b}_{\mathrm{t}}(\mathrm{m})
\end{aligned}
$$

\section{Keterangan:}

$\mathrm{S}{ }_{\mathrm{t}} \quad$ : nilai peramalan pertama dengan single moving average

$\mathrm{S}_{\mathrm{t}} \quad$ : nilai peramalan kedua dengan double moving average

$\mathrm{F}_{\mathrm{t}+\mathrm{m}}$ : hasil peramalan dengan double moving average pada periode ke-m

$\mathrm{m}$ : periode ke depan yang diramalkan

\section{Metode Double Exponential Smoothing}

$$
\begin{aligned}
& \mathrm{S}^{\prime}=\alpha \cdot \mathrm{X}_{\mathrm{t}}+(1-\alpha) \mathrm{S}^{\prime}{ }_{\mathrm{t}-1} \\
& \mathrm{~S}^{\prime}=\alpha \cdot \mathrm{S}_{\mathrm{t}}+(1-\alpha) \mathrm{S}^{\prime}{ }_{\mathrm{t}-1} \\
& \mathrm{a}_{\mathrm{t}}=2 \mathrm{~S}^{\prime}{ }_{\mathrm{t}}-\mathrm{S}^{\prime}{ }_{\mathrm{t}} \\
& \mathrm{b}_{\mathrm{t}}=\frac{\alpha}{1-\alpha}\left(S^{\prime} t-S^{\prime \prime} t\right) \\
& \mathrm{F}_{\mathrm{t}+\mathrm{m}}=\mathrm{a}_{\mathrm{t}}+\mathrm{b}_{\mathrm{tm}}
\end{aligned}
$$

\section{Metode Tren Linier}

$$
\begin{aligned}
\mathrm{Y} & =\mathrm{a}+\mathrm{bx} \\
\mathrm{b} & =\frac{n \sum X Y-\left(\sum X\right)\left(\sum Y\right)}{n \sum X^{2}-\left(\sum X\right)^{2}} \\
\mathrm{a} & =\frac{\sum Y}{n}-b \frac{\sum X}{n}
\end{aligned}
$$

Keterangan:

$\mathrm{Y}=$ nilai trend pada periode tertentu.

$\mathrm{a}=$ intersep dari persamaan trend.

$\mathrm{b}=$ koefisien kemiringan atau gradien dari persamaan trend yang menunjukkan besarnya suatu perubahan suatu unit pada $X$.

$\mathrm{X}=$ periode waktu. 
4. Metode Tren Kuadratik

$$
\begin{aligned}
& \mathrm{Y}=\mathrm{a}+\mathrm{bX}+\mathrm{c} X^{2} \\
& \mathrm{a}=\frac{\left(\sum Y\right)\left(\sum X^{4}\right)-\left(\sum X^{2} Y\right)\left(\sum X^{2}\right)}{n\left(\sum X^{4}\right)-\left(\sum X^{2}\right)^{2}} \\
& \mathrm{~b}=\frac{\sum X Y}{\sum X^{2}} \\
& \mathrm{c}=\frac{n\left(\sum X^{2} Y\right)-\left(\sum X^{2}\right)\left(\sum Y\right)}{n\left(\sum X^{4}\right)-\left(\sum X^{2}\right)^{2}}
\end{aligned}
$$

Keterangan:

$\mathrm{Y}=$ nilai trend yang ditaksir

$\mathrm{a}=$ konstanta

$\mathrm{b}=$ pengubah

$\mathrm{c}=$ pengubah

$\mathrm{X}=$ waktu

\section{Metode ARIMA}

Model AR (p)

$$
\mathrm{Y}_{\mathrm{t}}=\delta+\varphi_{1} \mathrm{Y}_{\mathrm{t}-1}+\varphi_{2} \mathrm{Y}_{\mathrm{t}-2}+\varphi_{3} \mathrm{Y}_{\mathrm{t}-3}+\ldots+\varphi_{\mathrm{p}} \mathrm{Y}_{\mathrm{t}-\mathrm{p}}+\mathrm{e}_{\mathrm{t}}
$$

Model MA (q)

$$
Y_{t}=\delta+e_{t}-\phi_{1} e_{t-1}-\phi_{2} e_{t-2}+\ldots+\phi_{q} e_{t-q}
$$

Model ARIMA (p,d,q)

$$
\begin{aligned}
& \left.\mathrm{Y}_{\mathrm{t}}=\delta+\left(1+\varphi_{1}\right) \mathrm{Y}_{\mathrm{t}-1}+\left(\varphi_{2}-\varphi_{1}\right) \mathrm{Y}_{\mathrm{t}-2}+\ldots+\left(\varphi_{\mathrm{p}}-\varphi_{\mathrm{p}-1}\right) \mathrm{Y}_{\mathrm{t}-\mathrm{p}}+\varphi_{\mathrm{p}} \mathrm{Y}_{\mathrm{t}-\mathrm{p}-1}\right)+\mathrm{e}_{\mathrm{t}}-\phi_{1} \mathrm{e}_{\mathrm{t}-1}- \\
& \phi_{2} \mathrm{e}_{\mathrm{t}-2}+\ldots+\phi_{\mathrm{q}} \mathrm{e}_{\mathrm{t}-\mathrm{q}}
\end{aligned}
$$

\section{HASIL DAN PEMBAHASAN}

\section{Jumlah Penduduk dan Kepadatan Penduduk}

\section{Jumlah Penduduk}

Tabel 2. Jumlah Penduduk Provinsi Nusa Tenggara Barat Menurut Kabupaten/Kota

\begin{tabular}{lcc}
\hline \multirow{2}{*}{ Kabupaten/Kota } & \multicolumn{2}{c}{ Penduduk (Ribu) } \\
\cline { 2 - 3 } & 2010 & 2019 \\
\hline Lombok Barat & 602.312 & 694.985 \\
Lombok Tengah & 863.061 & 947.488 \\
Lombok Timur & 1.109 .253 & 1.200 .612 \\
Sumbawa & 417.090 & 457.671 \\
Dompu & 219.685 & 252.288 \\
Bima & 440.704 & 488.577 \\
Sumbawa Barat & 115.526 & 148.606 \\
Lombok Utara & 200.730 & 220.412 \\
Kota Mataram & 404.502 & 486.715 \\
Kota Bima & 143.199 & 173.031 \\
\hline \multicolumn{1}{c}{ Nusa Tenggara Barat } & $\mathbf{4 . 5 1 6 . 0 6 2}$ & $\mathbf{5 . 0 7 0 . 3 8 5}$ \\
\hline
\end{tabular}

Sumber: NTB Dalam Angka 2020 
Berdasarkan Tabel 2, diketahui jumlah penduduk Provinsi Nusa Tenggara Barat pada tahun 2010 dan 2019 secara berturut-turut adalah sebanyak 4.516.062 jiwa dan 5.070.385 jiwa, jumlah tersebut mengalami pertumbuhan sebesar 12,27\%. Pada tahun 2010 dan 2019 jumlah penduduk tertinggi berada di Kabupaten Lombok Timur yaitu masing-masing sebanyak 1.109.251 jiwa dan 1.200.612 jiwa, jumlah tersebut mengalai pertumbuhan sebesar 8,24\%, sementara itu pada tahun 2010 dan 2019 jumlah penduduk terendah berada di Kabupaten Sumbawa Barat dengan jumlah penduduk yaitu masingmasing sebanyak 115.526 jiwa dan 148.606 jiwa, walaupun demikian jumlah tersebut mengalami pertumbuhan sebesar $28,63 \%$.

\section{Kepadatan Penduduk}

Tabel 3. Kepadatan Penduduk Provinsi Nusa Tenggara Barat Menurut Kabupaten/Kota

\begin{tabular}{lcc}
\hline \multirow{2}{*}{ Kabupaten/Kota } & \multicolumn{2}{c}{ Kepadatan Penduduk per $\mathrm{Km}^{2}$} \\
\cline { 2 - 3 } & 2010 & 2019 \\
\hline Lombok Barat & 572 & 659 \\
Lombok Tengah & 738 & 810 \\
Lombok Timur & 691 & 748 \\
Sumbawa & 63 & 69 \\
Dompu & 95 & 109 \\
Bima & 100 & 111 \\
Sumbawa Barat & 62 & 80 \\
Lombok Utara & 248 & 272 \\
Kota Mataram & 6.599 & 7.940 \\
Kota Bima & 644 & 779 \\
\hline \multicolumn{1}{c}{ Nusa Tenggara Barat } & $\mathbf{2 2 4}$ & $\mathbf{2 5 2}$ \\
\hline
\end{tabular}

Sumber: NTB Dalam Angka 2020

Data kepadatan penduduk setiap kilometer perseginya menjelaskan tentang padat tidaknya penduduk yang menempati suatu wilayah. Semakin besar angka kepadatan penduduknya, semakin padat wilayah tersebut. Berdasarkan Tabel 3, diketahui pada tahun 2010 dan 2019 kepadatan penduduk tertinggi berada di Kota Mataram yaitu masing-masing sebanyak $6.599 \mathrm{jiwa} / \mathrm{Km}^{2}$ dan $7,940 \mathrm{jiwa} / \mathrm{Km}^{2}$, artinya secara rata-rata setiap satu kilometer persegi wilayah kota Mataram didiami oleh 6.599 penduduk pada tahun 2010 dan sebanyak 7.940 penduduk pada tahun 2019. Sementara itu pada tahun 2010 kepadatan penduduk terendah berada di Kabupaten Sumbawa Barat yaitu sebanyak 62 jiwa $/ \mathrm{Km}^{2}$, artinya secara rata-rata setiap satu kilometer persegi wilayah Kabupaten Sumbawa Barat didiami oleh 62 penduduk sedangkan pada tahun 2019 kepadatan penduduk terendah berada di Kabupaten Sumbawa yaitu sebanyak 69 jiwa $/ \mathrm{Km}^{2}$, artinya secara rata-rata setiap satu kilometer persegi wilayah Kabupaten Sumbawa didiami oleh 6.599 penduduk.

\section{Metode Peramalan Terbaik}

Berdasarkan Tabel 4, diketahui dalam meramalkan produksi jagung untuk 6 tahun ke depan, metode peramalan yang digunakan adalah metode Double Moving Average karena memiliki nilai MAD, MSD dan MAPE terkecil yaitu masing-masing 
sebesar 103.785,01; 4.66435E+10; dan 11,92\%. Sementara itu, untuk meramalkan konsumi jagung, metode peramalan yang digunakan adalah metode Double Moving Average karena memiliki nilai MAD, MSD dan MAPE terkecil yaitu masing-masing sebesar 99,3; 59.911,14; dan 1,66\%. Dan untuk meramalkan harga jagung, metode peramalan yang digunakan adalah Tren Kuadratik karena memiliki nilai MAD, MSD dan MAPE terkecil yaitu masing-masing 298,42; 177.767,53; dan 6,37\%.

Tabel 4. Nilai MAPE, MAD dan MSD Masing-Masing Metode Peramalan Produksi, Konsumsi dan Harga Jagung di Provinsi Nusa Tenggara Barat

\begin{tabular}{clccc}
\hline \multirow{2}{*}{ Peramalan } & \multicolumn{3}{c}{ Metode Peramalan } & \multicolumn{3}{c}{ Kesalahan Peramalan } \\
\cline { 2 - 5 } & Double Moving Average & $11,92 \%$ & $103.785,01$ & $4.66435 \mathrm{E}+10$ \\
& Double Exponential Smoothing & $16,37 \%$ & $107.310,47$ & $4.22151 \mathrm{E}+10$ \\
& Produksi & $163,66 \%$ & $316.495,39$ & $1.29370 \mathrm{E}+11$ \\
& Metode Trend Linier & $51,35 \%$ & 113.203 & $2.07182 \mathrm{E}+10$ \\
& Metode Trend Kuadratik & - & - & - \\
\hline \multirow{5}{*}{ Konsumsi } & ARIMA & $1,66 \%$ & 99,93 & $59.911,14$ \\
& Double Moving Average & $12,50 \%$ & 719,34 & $1.183 .162,7$ \\
& Double Exponential Smoothing & $12,57 \%$ & 736,34 & $962.194,9$ \\
& Metode Trend Linier & $12,56 \%$ & 734,56 & $961.793,11$ \\
& Metode Trend Kuadratik & - & - & - \\
\hline \multirow{5}{*}{ Harga } & ARIMA & $7,06 \%$ & 351,36 & $276.554,35$ \\
& Double Moving Average & $6,10 \%$ & 303,96 & $224.591,51$ \\
& Double Exponential Smoothing & $10,26 \%$ & 463,55 & $337.948,15$ \\
& Metode Trend Linier & $6,37 \%$ & 298,42 & $177.767,53$ \\
& Metode Trend Kuadratik & $12,20 \%$ & 615,27 & $691.930,32$ \\
\hline
\end{tabular}

Sumber: Data Sekunder Diolah (2020)

Sementara itu dalam metode peramalan ARIMA, data produksi dan data konsumsi yang dimiliki untuk memproyeksikan produksi dan konsumsi jagung untuk periode 6 tahun ke depan tidak memiliki model estimasi ARIMA yang cocok dengan data yang dimiliki. Karena tidak semua data memiliki model estimasi ARIMA (Saludin, 2017).

\section{Hasil Proyeksi Produksi, Konsumsi dan Harga Jagung di Nusa Tenggara Barat Hasil Proyeksi Produksi Jagung di Provinsi Nusa Tenggara Barat}

Dalam analisis data yang telah dilakukan, didapatkan nilai konstanta (a) = $2.539 .898,44$ dan nilai slope $(b)=362.356,46$. Nilai konstanta (a) diperoleh dari diperoleh dari selisih antara dua dikali nilai average pertama dengan nilai average kedua. Sementara itu nilai slope (b) diperoleh dari dua dikali hasil selisih antara average pertama dengan average kedua kemudian dibagi dengan dua.

$$
\begin{aligned}
\mathrm{a} & =2 \mathrm{~S}_{\mathrm{t}}{ }^{\prime}-\mathrm{S}_{\mathrm{t}}{ }^{\prime}{ }^{\prime} \\
& =(2 \times 1.996 .363,75)-1.452 .829,06 \\
& =2.539 .898,44 \\
\mathrm{~b} & =\frac{2}{N-1}\left(S_{t}^{\prime}-S_{t}^{\prime \prime}\right) \\
& =\frac{2(1.996 .363,75-1.452 .829,06)}{3}=362.356,46
\end{aligned}
$$


Sehingga dari perhitungan tersebut, persamaan model dapat ditulis sebagai berikut: $\mathrm{F}_{\mathrm{t}}=\mathrm{a}_{\mathrm{t}}+\mathrm{b}_{\mathrm{t}}(\mathrm{m})$ $\mathrm{F}_{\mathrm{t}}=2.539 .898,44+362.356,46(\mathrm{~m})$

Dari persamaan model tersebut, maka dapat dihitung jumlah proyeksi produksi jagung di Provinsi Nusa Tenggara Barat. Dari perhitungan estimasi tersebut, produksi jagung di Provinsi Nusa Tenggara barat untuk jangka waktu 6 tahun ke depan (20202025) akan terus mengalami peningkatan. Ringkasnya dapat dilihat pada tabel dibawah ini.

Tabel 5. Proyeksi Produksi Jagung Di Provinsi NTB Dengan Menggunakan Metode Double Moving Average

\begin{tabular}{ccc}
\hline $\begin{array}{c}\text { Tahun Peramalan ke- } \\
(\mathbf{m})\end{array}$ & Tahun & $\begin{array}{c}\text { Proyeksi Produksi } \\
\text { (Ton) }\end{array}$ \\
\hline 1 & 2020 & $2.902 .254,90$ \\
2 & 2021 & $3.264 .611,35$ \\
3 & 2022 & $3.626 .967,81$ \\
4 & 2023 & $3.989 .324,27$ \\
5 & 2024 & $4.351 .680,73$ \\
6 & 2025 & $4.714 .037,19$ \\
\hline
\end{tabular}

Sumber: Data Sekunder diolah (2020)

Berdasarkan Tabel 5, diketahui proyeksi produksi jagung pada tahun 2020 adalah sebanyak 2.902.254,90 ton, ramalan produksi ini mengalami peningkatan sebesar 16,33\% dari tahun 2019. Sementara itu pada tahun 2021 produksi jagung diproyeksikan sebanyak 3.264.611,35 ton, mengalami peningkatan sebesar 12,49\%. Pada 2022 diproyeksikan produksi jagung di Provinsi NTB akan sebanyak 3.626.967,81 ton dengan peningkatan sebesar 11,10\%. Pada tahun 2023 produksi jagung diproyeksikan sebanyak 3.989.324,27 ton dengan persentase peningkatan sebesar 9,99\%. Pada tahun 2024 diproyeksikan produksi jagung akan sebanyak 4.351.680,73 ton dengan persentase peningkatan sebesar 9,08\%. Dan pada tahun 2025 produksi jagung di Provinsi NTB diproyeksikan akan sebanyak 4.714.037,19 ton dengan persentase peningkatan sebesar $8,33 \%$, sehingga rata-rata perkembangan produksi jagung di Provinsi NTB adalah sebesar 11,22\%.

\section{Hasil Proyeksi Konsumsi Jagung di Provinsi Nusa Tenggara Barat}

Dalam analisis data yang telah dilakukan, didapatkan nilai konstanta (a) = $7.151,44$ dan nilai slope $(b)=296,44$. Nilai konstanta (a) diperoleh dari selisih antara dua dikali nilai average pertama dengan nilai average kedua. Sementara itu nilai slope (b) diperoleh dari dua dikali hasil selisih antara average pertama dengan average kedua kemudian dibagi dengan dua.

$$
\begin{aligned}
\mathrm{a} & =2 \mathrm{~S}_{\mathrm{t}}{ }^{\prime}-\mathrm{S}_{\mathrm{t}}{ }^{\prime}{ }^{\prime} \\
& =(2 \times 6.855)-6.559 \\
& =7.151,44 \\
\mathrm{~b} & =\frac{2}{N-1}\left(S_{t}^{\prime}-S_{t}^{\prime \prime}\right) \\
& =\frac{2(6.855-6.559)}{2}=296,44
\end{aligned}
$$


Sehingga dari perhitungan tersebut diatas persamaan model untuk meramalkan jumlah konsumsi jagung dapat ditulis sebagai berikut:

$$
\begin{aligned}
& F_{t}=a_{t}+b_{t}(m) \\
& F_{t}=7.151,44+296,44(m)
\end{aligned}
$$

Dari persamaan model tersebut, maka dapat dihitung jumlah proyeksi konsumsi jagung di Provinsi Nusa Tenggara Barat. Dari perhitungan diatas jumlah proyeksi konsumsi jagung di Provinsi Nusa Tenggara barat untuk jangka waktu 6 tahun ke depan (2020-2025) diproyeksikan akan mengalami peningkatan. Ringkasnya pada tabel dibawah ini.

Tabel 6. Proyeksi Konsumsi Jagung Di Provinsi NTB Dengan Menggunakan Metode Double Moving Average

\begin{tabular}{ccc}
\hline $\begin{array}{c}\text { Tahun Peramalan ke- } \\
(\mathbf{m})\end{array}$ & Tahun & $\begin{array}{c}\text { Ramalan Konsumsi } \\
\text { (Ton) }\end{array}$ \\
\hline 1 & 2020 & $7.447,89$ \\
2 & 2021 & $7.744,33$ \\
3 & 2022 & $8.040,78$ \\
4 & 2023 & $8.337,22$ \\
5 & 2024 & $8.633,67$ \\
6 & 2025 & $8.930,11$ \\
\hline
\end{tabular}

Sumber: Data Sekunder diolah (2020)

Berdasarkan Tabel 6, diketahui proyeksi konsumsi jagung pada tahun 2020 adalah sebanyak 7.447,89 ton. Sementara itu pada tahun 2021 diproyeksikan konsumsi jagung di Provinsi Nusa tenggara Barat akan sebanyak 7.744,33 ton. Pada tahun 2022 konsumsi jagung diproyeksikan sebanyak 8.040,78 ton. Sedangkan pada tahun 2023 konsumsi jagung diproyeksikan akan sebanyak 8.337,22 ton. Pada tahun 2024 konsumsi jagung diproyeksikan sebanyak8.633,67 ton. Dan untuk tahun 2025 konsumsi jagung di Provinsi Nusa Tenggara Barat diproyeksikan sebanyak 8.930,11 ton. Sehingga rata-rata peningkatan konsumsi jagung adalah sebesar 7,03\%.

\section{Hasil Proyeksi Harga Jagung di Provinsi Nusa Tenggara Barat}

Dalam analisis peramalan harga jagung di Provinsi Nusa Tenggara barat nilai penimbang yang digunakan adalah $\alpha=0,1$ artinya memberikan bobot tingkat kesalahan 0,1 pada peramalan. Dalam analisis data yang telah dilakukan didapatkan nilai konstanta $(\mathrm{a})=5.380,41$ dan nilai slope $(\mathrm{b})=10,90$. Nilai konstanta (a) diperoleh dari selisih antara dua dikali smoothing pertama $\left(\mathrm{S}_{\mathrm{t}}{ }_{\mathrm{t}}\right)$ dengan smoothing kedua $\left(\mathrm{S}{ }_{\mathrm{t}}\right)$. Sementara itu nilai slope (b) diperoleh dari hasil kali penimbang $(\alpha=0,1)$ dengan selisih antara smoothing pertama $\left(\mathrm{S}_{\mathrm{t}}{ }_{\mathrm{t}}\right)$ dengan smoothing kedua $\left(\mathrm{S}^{\prime}{ }_{\mathrm{t}}\right)$ kemudian dibagi dengan $\beta=0,9(1-\alpha)$.

$$
\begin{aligned}
\mathrm{a} & =2 \mathrm{~S}_{\mathrm{t}}{ }^{\prime}-\mathrm{S}_{\mathrm{t}}{ }^{\prime}, \\
& =(2 \times 5.282,34)-5.184,27 \\
& =5.380,41 \\
\mathrm{~b} & =\frac{\alpha}{1-\alpha}\left(S_{t}^{\prime}-S_{t}^{\prime \prime}\right) \\
& =\frac{0,1(5.282,34-5.184,27)}{0,9} \\
& =10,90
\end{aligned}
$$


Sehingga daru perhitungan diatas, persamaan model Double Exponential Smoothing dapat ditulis sebagai berikut:

$$
\begin{aligned}
& \mathrm{F}_{\mathrm{t}}=\mathrm{a}_{\mathrm{t}}+\mathrm{b}_{\mathrm{t}}(\mathrm{m}) \\
& \mathrm{F}_{\mathrm{t}}=5.380,41+10.90(\mathrm{~m})
\end{aligned}
$$

Dari persamaan model tersebut, maka dapat dihitung proyeksi harga jagung di Provinsi Nusa Tenggara Barat. Proses perhitungan proyeksi harga jagung di Provinsi Nusa Tenggara Barat untuk tahun 2020 bulan Januari sampai tahun 2025 bulan Desember dapat dilihat pada tabel dibawah ini. Harga jagung di Provinsi Nusa Tenggara barat untuk jangka waktu 6 tahun ke depan (2020-2025) diproyeksikan akan mengalami kenaikan.

Tabel 7. Proyeksi Harga Jagung Di Provinsi NTB Dengan Menggunakan Metode

\begin{tabular}{|c|c|c|c|c|c|}
\hline Tahun & $\mathbf{x}$ & $\begin{array}{c}\text { Proyeksi } \\
\text { Harga }\end{array}$ & Tahun & $\mathbf{X}$ & $\begin{array}{c}\text { Proyeksi } \\
\text { Harga }\end{array}$ \\
\hline \multirow[t]{12}{*}{2020} & 1 & $5.391,30$ & \multirow[t]{12}{*}{2021} & 13 & $5.522,06$ \\
\hline & 2 & $5.402,20$ & & 14 & $5.532,96$ \\
\hline & 3 & $5.413,10$ & & 15 & 5.543 .85 \\
\hline & 4 & $5.423,99$ & & 16 & $5.554,75$ \\
\hline & 5 & $5.434,89$ & & 17 & $5.565,65$ \\
\hline & 6 & $5.445,79$ & & 18 & $5.576,54$ \\
\hline & 7 & $5.456,68$ & & 19 & $5.587,44$ \\
\hline & 8 & $5.467,58$ & & 20 & $5.598,34$ \\
\hline & 9 & $5.478,48$ & & 21 & $5.609,23$ \\
\hline & 10 & 5.489 .37 & & 22 & $5.620,13$ \\
\hline & 11 & $5.500,27$ & & 23 & $5.631,03$ \\
\hline & 12 & $5.511,17$ & & 24 & $5.641,92$ \\
\hline Jumlah & & $65.414,81$ & Jumlah & & $66.983,91$ \\
\hline Rata-Rata & & $5.451,23$ & Rata-Rata & & $5.581,99$ \\
\hline Tahun & $\mathbf{x}$ & $\begin{array}{c}\text { Proyeksi } \\
\text { Harga }\end{array}$ & Tahun & $\mathbf{X}$ & $\begin{array}{c}\text { Proyeksi } \\
\text { Harga }\end{array}$ \\
\hline \multirow{12}{*}{2022} & 25 & $5.652,82$ & \multirow[t]{12}{*}{2023} & 37 & $5.783,58$ \\
\hline & 26 & $5.663,72$ & & 38 & $5.794,47$ \\
\hline & 27 & $5.674,61$ & & 39 & $5.805,37$ \\
\hline & 28 & $5.685,51$ & & 40 & $5.816,27$ \\
\hline & 29 & $5.696,41$ & & 41 & $5.827,16$ \\
\hline & 30 & $5.707,30$ & & 42 & $5.838,06$ \\
\hline & 31 & $5.718,20$ & & 43 & $5.848,96$ \\
\hline & 32 & $5.729,10$ & & 44 & $5.859,85$ \\
\hline & 33 & $5.739,99$ & & 45 & $5.870,85$ \\
\hline & 34 & $5.750,89$ & & 46 & $5.881,65$ \\
\hline & 35 & $5.761,79$ & & 47 & $5.892,54$ \\
\hline & 36 & $5.772,68$ & & 48 & $5.903,44$ \\
\hline Jumlah & & $68.553,01$ & Jumlah & & $70.122,11$ \\
\hline Rata-Rata & & $5.712,75$ & Rata-Rata & & $5.843,51$ \\
\hline
\end{tabular}
Double Exponential Smoothing 


\begin{tabular}{|c|c|c|c|c|c|}
\hline Tahun & $\mathbf{x}$ & $\begin{array}{c}\text { Proyeksi } \\
\text { Harga }\end{array}$ & Tahun & $\mathbf{X}$ & $\begin{array}{c}\text { Proyeksi } \\
\text { Harga }\end{array}$ \\
\hline \multirow[t]{12}{*}{2024} & 49 & $5.914,34$ & 2025 & 61 & $6.045,10$ \\
\hline & 50 & $5.925,23$ & & 62 & $6.055,99$ \\
\hline & 51 & $5.936,13$ & & 63 & $6.066,89$ \\
\hline & 52 & $5.947,03$ & & 64 & $6.077,78$ \\
\hline & 53 & $5.957,92$ & & 65 & 6.088 .68 \\
\hline & 54 & $5.968,82$ & & 66 & $6.099,58$ \\
\hline & 55 & $5.979,72$ & & 67 & $6.110,47$ \\
\hline & 56 & $5.990,61$ & & 68 & $6.121,37$ \\
\hline & 57 & $6.001,51$ & & 69 & $6.132,27$ \\
\hline & 58 & $6.012,41$ & & 70 & $6.143,16$ \\
\hline & 59 & $6.023,30$ & & 71 & $6.154,06$ \\
\hline & 60 & $6.034,20$ & & 72 & $6.164,96$ \\
\hline Jumlah & & $71.691,21$ & Jumlah & & $73.260,31$ \\
\hline Rata-Rata & & $5.974,27$ & Rata-Rata & & $6.105,03$ \\
\hline
\end{tabular}

Sumber: Data Sekunder Diolah 2020

Berdasarkan Tabel 7, diketahui proyeksi rata-rata harga jagung pada tahun 2020 adalah sebesar Rp. 5.451,23. Sementara itu pada tahun 2021 harga jagung di Provinsi Nusa Tenggara Barat diproyeksikan akan sebesar Rp. 5.581,99. Pada tahun 2022 harga jagung di Provinsi Nusa Tenggara Barat akan sebesar Rp. 5.712,57. Sedangkan pada tahun 2023 harga jagung akan sebesar Rp. 5.843,51. Pada tahun 2024 harga jagung akan sebesar Rp. 5.974,27. Dan pada tahun 2025 harga jagung di Provinsi Nusa Tenggara Barat diproyeksikan akan sebesar Rp. 6.105,03.

\section{KESIMPULAN DAN SARAN}

\section{Kesimpulan}

1. Hasil proyeksi jumlah produksi jagung di Provinsi Nusa Tenggara Barat pada tahun 2021 adalah sebanyak 2.902.254,90 ton, pada tahun 2021 sebanyak 3.264.611,35 ton, pada tahun 2022 sebanyak 3.626.967,81 ton, pada 2023 sebanyak 3.989.324,27 ton, pada tahun 2024 sebanyak 4.351.680,73 ton dan pada tahun 2025 diproyeksikan sebanyak 4.714.037,19 ton.

2. Hasil proyeksi jumlah konsumsi jagung di Provinsi Nusa Tenggara barat pada tahun 2020 adalah sebanyak 7.447,89 ton, pada tahun 2021 sebanyak 7.744,33 ton, pada tahun 2022 sebanyak 8.040,78 ton, pada tahun 2023 sebanyak 8.337,22 ton, pada tahun 2024 sebanyak 8.633,67 ton dan pada tahun 2025 diproyeksikan sebanyak 8.930,11 ton.

3. Hasil proyeksi harga jagung di Provinsi Nusa Tenggara barat pada tahun 2020 jika di rata-ratakan adalah sebesar Rp. 5.451, pada tahun 2021 sebesar Rp. 5.581, pada tahun 2022 sebesar Rp. 5.712, pada tahun 2023 sebesar Rp. 5.843, pada tahun 2024 sebesar Rp. 5.974 dan pada tahun 2025 diproyeksikan sebesar Rp. 6.105. 


\section{Saran}

Berdasarkan hasil analisis dan proyeksi jumlah produksi, jumlah konsumsi dan harga jagung yang telah dilakukan, maka dapat disampaikan beberapa saran untuk dinas-dinas terkait sebagai berikut: mengusahakan untuk tercapainya jumlah proyeksi produksi jagung, menjaga stabilitas harga jagung dan dapat meningkatkan konsumsi masyarakat terhadap jagung dan menciptakan suatu ekosistem yang daat menampung kelebihan produksi jagung yang ada di Provinsi Nusa Tenggara Barat seperti menciptakan industri pengolahan jagung, industri pabrik pakan ternak dan sebagainya.

\section{DAFTAR PUSTAKA}

Vaus, D (2005). Survey in Social Reasearch. London: Routledge.

Nazir, Moh. (2013). Metode Penelitian. Ghalia Indonesia. Bogor.

Saludin. 2017. Ekonometrika Keuangan Aplikasi Permodelan Dengan Minitab. Mitra Wacana Media. Jakarta. 